Check for updates

Cite this: RSC Adv., 2019, 9, 23119

Received 27th February 2019

Accepted 29th June 2019

DOI: 10.1039/c9ra01505a

rsc.li/rsc-advances

\section{Extraction of DNA from complex biological sample matrices using guanidinium ionic liquid modified magnetic nanocomposites $\uparrow$}

\author{
Mei Liu, Xueqin Ding, (D) * Xuelian Wang, Jianzhong Li, ${ }^{*}$ Huansheng Yang \\ and Yulong Yin
}

A series of guanidinium ionic liquid modified magnetic chitosan/graphene oxide (GIL-MCGO) nanocomposites have been prepared for DNA extraction via magnetic solid-phase extraction technology. These nanocomposites are of only 20 nanometers in diameter. Single stranded DNA or DNA sodium salts that were absorbed by GIL-MCGO could be quickly collected by an external magnet and extracted. The DNA extraction efficiency of 11 GIL-MCGO nanocomposites was evaluated using NanoDrop. Factors that could impact the DNA extraction process, such as $\mathrm{pH}$, temperature, extraction time, and ionic strength were systematically investigated via single-factor experimental analysis. Under the optimum extraction conditions, a maximum DNA extraction capacity of $233.0 \pm 0.4 \mathrm{mg} \mathrm{g}^{-1}$ of GILMCGO nanocomposite was achieved. The solid phase extraction method based on GIL-MCGO nanocomposites has been demonstrated with the extraction of DNA from a series of complex sample matrices, including single stranded DNA samples, salmon sperm DNA sodium salt, human whole blood and E. coli cell lysate. The DNA extracted by using the GIL-MCGO nanocomposites are well suitable for PCR amplifications. In addition, an initial study on the interaction between GIL-MCGO and DNA was conducted: the preference of GIL-MCGO on DNA absorption with varying base composition was tested. Only a slight loss in the DNA extraction efficiency of GIL-MCGO was observed after four extractiondesorption cycles, proving excellent regeneration performance and recyclability of the GIL-MCGO nanocomposites in the DNA extraction process.

\section{Introduction}

Highly accurate and reliable DNA analysis is the foundation of various biological applications..$^{1-3}$ However, separating DNA with high purity from the cell matrix or from biological samples in a complex environment is proven to be extremely complicated and challenging., ${ }^{4,5}$ Proteins, metal ions, etc. are all common impurities in DNA involved downstream applications. ${ }^{6,7}$ Traditional DNA purification technology is realized by using phenol-chloroform liquid-liquid extraction system. ${ }^{8}$ The liquid-liquid extraction method suffers from the necessity of using great amounts of solvents. More recently, solid-phase extraction (SPE) technology has been developed and several DNA extraction kits are commercialized. ${ }^{9}$ These commercial SPE kits provide reduction on solvent usage and analysis time, however, some of the products require multiple centrifugation and transfer processes, which will easily result in extra time and human power consumption, and loss of DNA content; ${ }^{10}$ some

School of Life Sciences, Hunan Normal University, Changsha, Hunan, China 410081. E-mail: xueqinding@hunnu.edu.cn

$\dagger$ Electronic supplementary information (ESI) available. See DOI: 10.1039/c9ra01505a other products tend to utilize very expensive magnetic beads, with poor reusability. ${ }^{11}$

Magnetic solid-phase extraction, originated from SPE technology, has been applied in DNA purification due to its advantage of easy separation procedure. ${ }^{12-14}$ Magnetic adsorbent plays a vital role in the magnetic SPE procedure. It requires a magnetic core to facilitate separation and a coexisting absorbing component to extract DNA in the purification process..$^{15}$

Implementation of magnetic core avoids the necessity of adsorbent being packed into the SPE cartridges and the centrifuge steps in traditional SPE can be substituted by an external magnetic field to achieve solid-liquid separation. ${ }^{16}$ In preparing the magnetic core of the absorbents, chitosan, a basic polysaccharide polymer with bifunctional groups, has been reported as one of the surface modification materials. ${ }^{17-19}$ In the presence of glutaraldehyde, $\mathrm{Fe}_{3} \mathrm{O}_{4}$ can be modified by chitosan to form magnetic chitosan (MC) particles. These particles can be easily being functionalized, activated and coupled because of a multitude of chemically active amino and hydroxyl groups in its molecular structure..$^{20-22}$

Recently, some researchers have explored the potential of chitosan-graphene oxide (GO) composite as biological 
adsorbents, where carboxyl group of GO chemically reacts with amine group of chitosan and consequently forming chemical bond between GO and chitosan. ${ }^{23,24} \mathrm{GO}$ contains a wide range of oxygen functional groups both on the basal planes and at the edges of GO sheets, such as $-\mathrm{COOH}$ and $-\mathrm{OH} .{ }^{23}$ These functional groups are expected to promote interfacial interactions between GO and adsorbate, which are essential for efficient extraction of macromolecules. ${ }^{25}$ However, the chitosan-GO composites are easy to aggregate. Therefore, it is important to develop a new material to overcome the aggregation and efficiently extract biomolecules. In the past years, ionic liquids (ILs) have been reported several times to be immobilized onto GO surface as adsorbents in SPE to prevent the aggregation of GO. ${ }^{26-28}$ ILs are widely recognized as solvents and dispersants that can be designed to be environmentally benign. ${ }^{29-31}$ Guanidinium ionic liquid (GIL), as a member of ILs family, has good biological compatibility and thermal/chemical stability, and can be easily prepared. ${ }^{32}$ In our previous work, we synthesized several guanidinium ILs and explored their application in protein purification and ingredient extraction from traditional Chinese medicine. ${ }^{33-35}$ Moreover, guanidinium ILs has good designability and compatibility with other components to form composites due to adjustability of its three nitrogen-atoms. Although the liquidity of ILs is lost when they are immobilized onto GO surface, other properties such as polarity and low volatility are maintained. ${ }^{36,37}$ Based on the properties of IL as well as the strong electrostatic/chemical interaction between IL and GO, the introduction of IL into functional composites could not only alleviate aggregation but also might increase the watersolubility. ${ }^{38,39}$ In addition, IL can physically interact with the -OH group of chitosan via hydrogen bonding, to enhance the stability and strength of the multi-components composite.

In this paper, a series of guanidinium ILs modified magnetic chitosan graphene oxide (GIL-MCGO) nanocomposites with smaller size (20 nanometers in diameter) have been prepared for DNA purification. The optimized GIL-MCGO based extraction procedures are capable of performing rapid and highly efficient extraction of single-stranded and double-stranded DNA from a matrix containing metal ions and/or proteins. Genomic DNA extracted from human whole blood and plasmid DNA (pDNA) extracted from a bacterial cell lysate using this method were shown to be a high-quality template for PCR (as shown in Scheme 1).

\section{Experimental}

\section{Apparatus}

GIL-MCGO nanocomposites were dried by a Labconco FreeZone freeze dryer (Kansas City, MO, USA). All batch extraction experiments were performed on a ZWY-240 thermostats cultivating shaker (Shanghai, China). Concentration of DNA was determined by a Thermo Scientific NanoDrop 2000 spectrophotometer (Waltham, MA, USA). The magnetic hysteresis and morphology of GIL-MCGO nanocomposites were characterized by a MicroSense EV11 Vibrating Sample Magnetometer (Lowell, MA, USA), a STA 409 PC Thermogravimetric analysis (Germany) and a Hitachi HT-7700 transmission electron microscope (Tokyo, Japan), respectively.
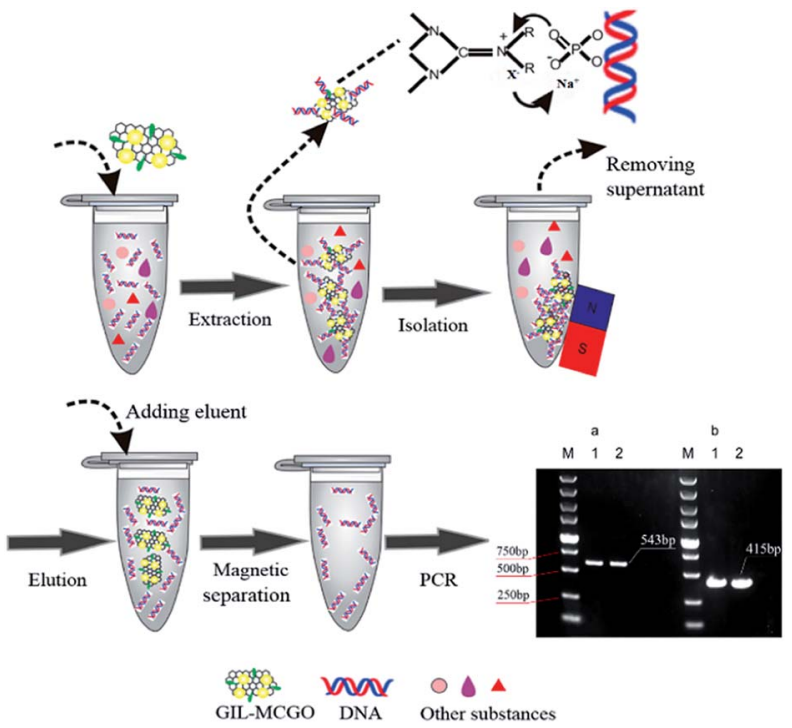

Scheme 1 The process of DNA purification.

\section{Reagents and materials}

Chitosan with viscosity of 100-200 mPas, 95\% degree of deacetylation, and methylacrylic acid ( $\geq 99.5 \%)$, propionic acid ( $\geq 99.5 \%$ ), $n$-butyl bromide ( $\geq 98 \%$ ), acrylic acid ( $\geq 99 \%$ ), 1 bromohexane (99\%), 1-bromooctane ( $\geq 99 \%)$, anhydrous magnesium sulfate $(99.9 \%)$, potassium carbonate $(\geq 99 \%)$, tetrabutylammonium bromide (99\%), sodium bromide (99\%), paraffin liquid $(\geq 99 \%)$ and bovine hemoglobin were all purchased from Macklin Biochemical Technology Co., Ltd (Shanghai, China). Single layer graphene oxide with a thickness of 0.8-1.2 nm was purchased from Xianfeng Nano Material Technology Co., Ltd (Nanjing, China). Salmon sperm DNA sodium salt, $\mathrm{KCl}, \mathrm{CaCl}_{2} \cdot 2 \mathrm{H}_{2} \mathrm{O}, \mathrm{MgCl}_{2} \cdot 6 \mathrm{H}_{2} \mathrm{O}$ were purchased form Sigma-Aldrich Co. Llc (St. Louis, MO, USA). 1-Ethyl-3-(3dimethylaminopropyl)carbodiimide hydrochloride (EDC) and $N$-hydroxysuccinimide (NHS) were purchased from Adams Reagent Co., Ltd. (Shanghai, China). 1,1,3,3-tetramethylguanidine (TMG, 99\%), acetate ( $\geq 99.8 \%$ ), fomate acid $(\geq 98 \%$ ), itaconic acid $(\geq 99 \%)$, maleic acid $(\geq 99 \%)$, iron(III) oxide, span тм 80 were purchased from Aladdin Reagent Co., Ltd. (Shanghai, China). DL-lactic acid $(\geq 85 \%)$, acetonitrile ( $\geq 99.8 \%)$, dichloromethane ( $\geq 99.8 \%$ ), activated carbon, $\mathrm{NaOH}, \mathrm{NaCl}$, $\mathrm{H}_{3} \mathrm{PO}_{4}(\geq 80 \%), \mathrm{H}_{3} \mathrm{BO}_{3}$, 1-butanol ( $\left.\geq 99 \%\right)$, methanol ( $\left.\geq 99.5 \%\right)$, ethanol $(\geq 99.7 \%)$, glucose were procured from Sinopharm Chemical Reagent Co., Ltd. (Shanghai, China). Petroleum ether $(\geq 95 \%)$, EDTA-2Na ( $\geq 99 \%)$ and glutaraldehyde solution $(50 \%$ in $\mathrm{H}_{2} \mathrm{O}$ ) were purchased from Huihong Reagent Co., Ltd (Hunan, China). Plasmid miniprep kit, animal genomic DNA kit, double-stranded and single-stranded DNA, proteinase $\mathrm{k}$ were purchased from Qingke Biotechnology Co., Ltd. (Hunan, China). Agarose M, Tris-HCl (>99.9\%), SDS (>97\%) were purchased from Sangon Biotech Co., Ltd. (Shanghai, China). $2 \times$ Taq plus master mix (dye plus) was purchased from Vazyme Biotech Co., Ltd. (Nanjing, China). DL-5000 DNA Marker was purchased from Takara Co., Ltd. (Beijing, China). 


\section{Synthesis of ionic liquid}

Eight tetraalkylguanidinium-based ILs (Fig. 1a-h) consist of 1,1,3,3-tetramethylguanidinium cation and different anions were directly synthesized by neutralization of 1,1,3,3-tetramethylguanidine (TMG) and acids. ${ }^{34,35}$ Three hexaalkylguanidinium-based ILs (Fig. 1i-k) which have the same anion with different cation were prepared by stirring a mixture of TMG, haloalkanes, tetrabutylammonium bromide and potassium carbonate at $60{ }^{\circ} \mathrm{C} .{ }^{33}$ The reaction conditions including the amount of reactant, reaction time and temperature, etc. are shown in the ESI. $\dagger$ All of the ILs were dried under vacuum at $70{ }^{\circ} \mathrm{C}$ for $24 \mathrm{~h}$ before use.

\section{Extraction of synthetic oligonucleotide and salmon sperm DNA sodium salt}

For extraction of synthetic oligonucleotide, a 20-base oligonucleotide with sequence of 5'-ACG GTG CCC ATC TAC GAG GG-3' and a 21-base oligonucleotide with sequence of $5^{\prime}$-TGA TGT CCC GCA CGA TCT CCC-3' ${ }^{\prime}$ were dissolved in TE buffer (pH 8) separately with a final concentration of $1000 \mathrm{nM}\left(7 \mathrm{ng} \mu \mathrm{L}^{-1}\right)$. Extraction experiments were performed on a thermostat a<smiles>CN(C)C(NOC=O)N(C)C</smiles>

d<smiles>C=C(C)C(=O)ONC(=NC)N(C)C</smiles>

[TMG] $\mathrm{CHC}\left(\mathrm{CH}_{3}\right) \mathrm{COOH}$ b<smiles>CC(=O)ONC(N(C)C)N(C)C</smiles>

[TMG] $\mathrm{CH}_{2} \mathrm{COOH}$

e

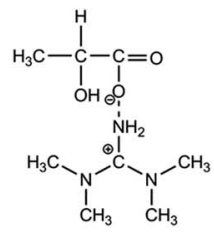

[TMG] $\mathrm{CH}_{2} \mathrm{CH}(\mathrm{OH}) \mathrm{COOH}$<smiles>CCC(=O)ONC(N(C)C)N(C)CCCCCC(=O)O</smiles>

$\mathbf{f}$<smiles>C=CC(=O)ONC(N(C)C)N(C)C</smiles>

[TMG]CHCHCOOH g<smiles>C=C(C(=O)OCC(=O)OCC(=O)OCC(=O)O)C(=O)ONC(N(C)C)N(C)C</smiles>

h<smiles>CN(C)C(NO)N(C)C</smiles>

[TMG]C(COOH) $\mathrm{CHCOOH}$

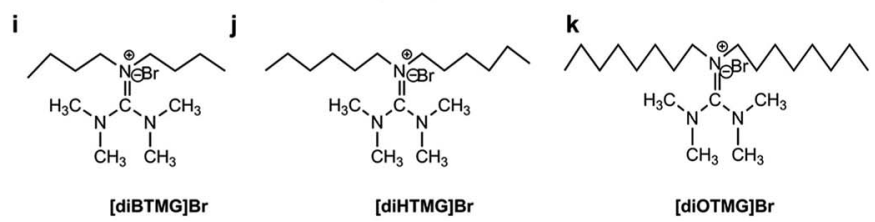

Fig. 1 Chemical structure of ionic liquids. cultivating shaker with a shaker speed of $400 \mathrm{rpm} .2 \mathrm{mg}$ synthetic GIL-MCGO nanocomposites are employed to extract $1 \mathrm{~mL}$ DNA solution for 30 minutes under $35 \pm 0.1{ }^{\circ} \mathrm{C}$. Subsequently, GIL-MCGO nanocomposites were separated by an external magnetic field and the concentration of DNA post extraction was measured at $260 \mathrm{~nm}$ using a NanoDrop 2000 spectrophotometer from Thermo Scientific. Extraction efficiency $(W \%)$ and extraction capacity $\left(Q \mathrm{mg} \mathrm{g}^{-1}\right)$ were calculated by:

$$
\begin{gathered}
W \%=1-\frac{C V}{C_{0} V_{0}} \times 100 \% \\
Q=\frac{\left(C_{0}-C\right) V}{m}
\end{gathered}
$$

where $C\left(\mathrm{ng} \mu \mathrm{L}^{-1}\right)$ and $V(\mathrm{~mL})$ represent the concentration and volume after extraction. $C_{0}\left(\mathrm{ng} \mu \mathrm{L}^{-1}\right)$ and $V_{0}(\mathrm{~mL})$ represent the concentration and volume before extraction. $m(\mathrm{mg})$ is the mass of GIL-MCGO nanocomposites.

For extraction of salmon sperm DNA sodium salt, $10 \mathrm{mg}$ synthetic GIL-MCGO nanocomposites are employed to extract an aqueous solution containing $7 \mathrm{ng} \mu \mathrm{L}^{-1}$ of $2000 \mathrm{bp}$ salmon sperm DNA sodium salt was prepared in TE buffer ( $\mathrm{pH} 8)$. The extraction was conducted with the same process as in the single stranded DNA extraction.

\section{Extraction of DNA from a complex matrix}

Sample matrices containing metal ions or protein $(\mathrm{BHb})$ were prepared from stock solution. For experiments involving metal ions as matrix components, the sample solution containing $22670 \mathrm{ng} \mu \mathrm{L}^{-1} \mathrm{NaCl}, 11400 \mathrm{ng} \mu \mathrm{L}^{-1} \mathrm{KCl}, 468 \mathrm{ng} \mu \mathrm{L}^{-1} \mathrm{CaCl}_{2}$, $5750 \mathrm{ng} \mu \mathrm{L}^{-1} \mathrm{MgCl}_{2}$, and $50 \mathrm{ng} \mu \mathrm{L}^{-1}$ DNA sodium salt was extracted in triplicate using $10 \mathrm{mg}$ synthetic GIL-MCGO nanocomposites. For experiments involving protein as a matrix component, the sample solution was prepared at an $\mathrm{BHb}$ concentration of $1000 \mu \mathrm{g} \mathrm{mL}{ }^{-1}$ and DNA concentration of 1000 $\mu \mathrm{g} \mathrm{mL}{ }^{-1}$ with the $\mathrm{pH}$ at 4 . BHb was measured at $406 \mathrm{~nm}$ using a NanoDrop 2000 spectrophotometer.

\section{Conditions for $E$. coli cell transformation}

E. coli $\mathrm{DH}-5 \alpha$ cells were transformed with a modified plasmid (PGEMT-Bmp4) containing 415 bp DNA insert. $1 \mu \mathrm{L}$ purified plasmid was added to a centrifuge tube which contains $50 \mu \mathrm{L}$ competent cells and mixed gently. The mixture was placed on ice for $30 \mathrm{~min}$ before heat at $80{ }^{\circ} \mathrm{C}$ for $80 \mathrm{~s}$, then chilled on ice immediately for $5 \mathrm{~min}$. $600 \mu \mathrm{L}$ non-resistant Luria Bertani (LB) medium was added to the sample. After being centrifuged at low speed, the sample was incubated at $37{ }^{\circ} \mathrm{C}$ for $12 \mathrm{~h}$. Single colony was selected and placed in a LB medium containing ampicillin (100 mL containing $50 \mathrm{mg} \mathrm{L}^{-1}$ ampicillin). E. coli cell cultures were cultured in a shaker for $12 \mathrm{~h}$ at $37^{\circ} \mathrm{C}$.

\section{Extraction of plasmid DNA from bacterial solution}

A $1.5 \mathrm{~mL}$ aliquot of $E$. coli cell culture was centrifuged at $12000 \mathrm{~g}$ for $1 \mathrm{~min}$, then resuspended in a $200 \mu \mathrm{L}$ solution $(\mathrm{pH} 8)$ containing $25 \mathrm{mmol} \mathrm{L}^{-1}$ Tris-HCl, $10 \mathrm{mmol} \mathrm{L}^{-1}$ EDTA-2Na and 
$50 \mathrm{mmol} \mathrm{L}^{-1}$ glucose. A $200 \mu \mathrm{L}$ solution containing $0.2 \mathrm{mmol}$ $\mathrm{L}^{-1} \mathrm{NaOH}$ and $1 \%$ SDS was added into the above sample with gentle mixing. A $200 \mu \mathrm{L}$ potassium acetate $\left(3 \mathrm{~mol} \mathrm{~L}^{-1}\right)$ and acetic acid $\left(2 \mathrm{~mol} \mathrm{~L}^{-1}\right)$ solution ( $\left.\mathrm{pH} 4.8\right)$ was then added and the final solution was diluted to $1000 \mu \mathrm{L}$ using $0.01 \mathrm{~mol} \mathrm{~L}^{-1} \mathrm{BR}$ buffer at pH 2. $1000 \mu \mathrm{L}$ cell lysate was adsorbed by $10 \mathrm{mg}$ GILMCGO nanocomposites for $10 \mathrm{~min}$. After pre-washing with $70 \%$ ethanol, the GIL-MCGO nanocomposites were eluted by $500 \mu \mathrm{L} 0.04 \mathrm{mmol} \mathrm{L}^{-1}$ BR buffer at $\mathrm{pH} 10$ and subjected to PCR assay.

\section{Extraction of genomic DNA from human whole blood}

Human whole blood samples from healthy volunteers were provided by Sanzhen Community Health Service Center (Changsha, China). All experiments were performed in accordance with the principles outlined in the Declaration of Helsinki, and Experiments were approved by the ethics committee at Hunan Normal University. Informed consents were obtained from human participants of this study. Blood samples were stored at $-20{ }^{\circ} \mathrm{C}$ for future use. A $200 \mu \mathrm{L}$ aliquot of human whole blood sample was mixed with $20 \mu \mathrm{L}$ proteinase $\mathrm{k}(20 \mu \mathrm{g}$ $\mu \mathrm{L}^{-1}$ ) and whirlpool for 10 s. $200 \mu \mathrm{L}$ buffer gA1 was added into the sample with thoroughly mixing. The mixture was then incubated in a water bath for 15 min under $70{ }^{\circ} \mathrm{C}$ before $200 \mu \mathrm{L}$ ethanol being added. The DNA in the lysate was extracted by $10 \mathrm{mg}$ GIL-MCGO nanocomposites for $10 \mathrm{~min}$. After washing several times, the GIL-MCGO nanocomposites have been separated and eluted by $500 \mu \mathrm{L} \mathrm{BR}$ buffer at $\mathrm{pH} 10\left(0.04 \mathrm{mmol} \mathrm{L}^{-1}\right)$ and subjected to PCR assay.

\section{Real-time quantitative PCR assays}

E. Coil cell lysate: PCR assay was performed using a $415 \mathrm{bp}$ Bmp4 gene fragment with forward primer 5'-CAAATAGATGACGCCTTCTC-3' (molecular weight $=6061.0 \mathrm{Da})$ and reverse primer 5'-GCTTTCGACCTCTTTGTTTA-3' (molecular weight $=6040.0 \mathrm{Da})$. The PCR mixture contains $1 \mu \mathrm{L}$ recovered pDNA, $2 \mu \mathrm{L}$ forward/reverse primer $\left(10 \mu \mathrm{mol} \mathrm{L}{ }^{-1}\right)$ and $25 \mu \mathrm{L}$ $2 \times$ Taq Plus Master Mix, with a final volume of $50 \mu \mathrm{L}$.

Human whole blood samples: PCR assay was performed using a 543 bp P53 gene fragment with forward primer $5^{\prime}$ CCACCATCCACTACAAC- $3^{\prime}$ (molecular weight $=5028.3 \mathrm{Da}$ ) and reverse primer 5'-GCTTGCTTACCTCGCTTAG-3' (molecular weight $=5745.8 \mathrm{Da})$. The PCR mixture contains $2 \mu \mathrm{L}$ recovered DNA, $2 \mu \mathrm{L}$ forward/reverse primer $\left(10 \mu \mathrm{mol} \mathrm{L} \mathrm{L}^{-1}\right)$ and $25 \mu \mathrm{L}$ $2 \times$ Taq Plus Master Mix, with a final volume of $50 \mu \mathrm{L}$.

PCR temperature program was $95{ }^{\circ} \mathrm{C}$ for $3 \mathrm{~min}, 30$ cycles at $90{ }^{\circ} \mathrm{C}$ for $15 \mathrm{~s}, 57{ }^{\circ} \mathrm{C}$ for $20 \mathrm{~s}, 72{ }^{\circ} \mathrm{C}$ for $1 \mathrm{~min}$, and finally extended at $72{ }^{\circ} \mathrm{C}$ for $10 \mathrm{~min}$.

\section{Results and discussion}

\section{Preparation of GIL-MCGO nanocomposites}

MCGO composites were prepared based on our previous work with certain modifications to have smaller size and increased surface to bulk ratio (the synthesis of GIL-MCGO nanocomposites is provided in ESI $\dagger$ ). In the presence of catalysts, carboxyl group of
GO chemically reacts with amine group of magnetic chitosan, consequently forming chemical bond between GO and chitosan. However, MCGO composites are easily aggregated and will affect its extraction performance. To mitigate the aggregation, guanidinium ILs are utilized to modify these MCGO composites. As observed in Rajesh's work, immobilization of ionic liquids on among nanocomposites to prevent aggregation and promote the dispersion of graphene oxide. ${ }^{40}$ Concurrently, hydroxyl groups of chitosan can also interact with nitrogen-containing ionic liquids to form intermolecular hydrogen bonds. ${ }^{41}$ By optimizing the preparation process, MCGO composites with smaller size have been obtained and were modified by different GILs for DNA extraction (TGA, FT-IR spectra of GIL-MCGO nanocomposites is in the ESI $\dagger$ ). In Fig. 2(a), the diameter of the GIL-MCGO nanocomposites is only about 20 nanometers (the size distribution of GIL-MCGO nanocomposites is in the ESI $\dagger$ ). Fig. 2(b) shows the magnetic hysteresis loop of the GIL-MCGO. It can be seen that the magnetic hysteresis loop was S-like shape and shows superparamagnetism of the nanocomposites. The maximum saturation magnetization of the GIL-MCGO nanocomposites is $14.0 \mathrm{emu} \mathrm{g}^{-1}$, which is sufficient for GIL-MCGO nanocomposites to be separated from their dispersion by an external magnetic field. Further, XRD pattern in the $\mathrm{ESI} \dagger$ shows the crystalline phase of $\mathrm{Fe}_{3} \mathrm{O}_{4}$ was unchanged in the GIL-MCGO nanocomposites.

\section{Extraction of synthetic oligonucleotide and salmon sperm DNA sodium salt}

MCGO nanocomposites have been modified by 11 different guanidinium ILs (8 anionic tetraalkylguanidinium-based ILs and 3 cationic hexaalkylguanidinium-based ILs, Fig. 1) for DNA extraction. For single stranded DNA extraction (20-base oligonucleotide and 21-base oligonucleotide), all of the GIL-MCGO nanocomposites have extracted DNA from the solution. But the extraction performance of the GIL-MCGO nanocomposites are varying, with extraction efficiencies ranging from 37.4 to 97.7\% (Fig. 3). The [TMG] $\mathrm{CH}_{2} \mathrm{CH}_{2} \mathrm{COOH}-\mathrm{MCGO}$ has the highest extraction efficiencies both in 20-base oligonucleotide and 21base oligonucleotide extraction. [diOTMG]Br-MCGO also has very high extraction efficiencies of $83 \pm 3 \%$ and $73 \pm 2 \%$, respectively.

In the case of salmon sperm DNA sodium salt extraction, the extraction efficiencies of GIL-MCGO nanocomposites are very different from those of synthetic oligonucleotide extraction. [diOTMG]Br-MCGO has the highest extraction efficiency of DNA sodium salt, reaching $79 \pm 2 \%$. [diHTMG]Br-MCGO also has high extraction efficiency of $65 \pm 4 \%$. As a contrast, the extraction efficiencies of anionic tetraalkylguanidinium-based ILs are relatively low, with the values around 20\%. [TMG] $\mathrm{CHCHCOOH}-\mathrm{MCGO}$ and [TMG]C(COOH)CHCOOH-MCGO have no adsorption of DNA sodium salt. Thus, the extraction performance of various GIL modified MCGO nanocomposites is highly dependent on specific DNA species.

\section{Optimization of extraction process}

[diOTMG]Br-MCGO was selected to optimize extraction condition of the magnetic solid-phase extraction procedure, due to its 

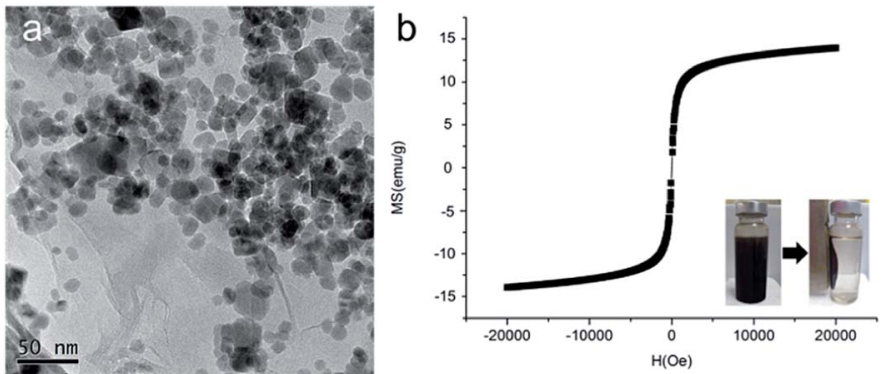

Fig. 2 TEM image (a) and magnetic hysteresis loop (b) of GIL-MCGO nanocomposites.
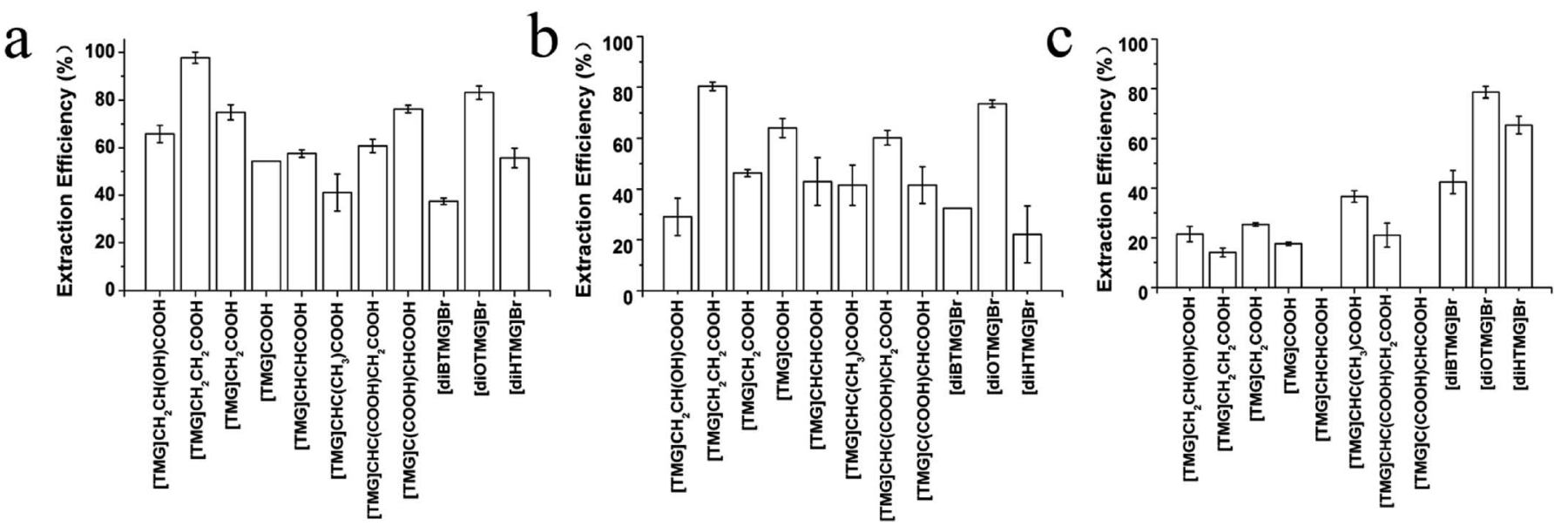

Fig. 3 Extraction efficiencies of 20-base oligonucleotide (a); 21-base oligonucleotide (b) and DNA sodium salt (c) by different GIL-MCGO nanocomposites. GIL-MCGO nanocomposites: $2 \mathrm{mg}$; DNA solution: $7 \mathrm{ng} \mu \mathrm{L}^{-1}, 1 \mathrm{~mL}$; extraction time: $30 \mathrm{~min}$.

high DNA extraction efficiency shown in the initial tests. Several factors, such as $\mathrm{pH}$, temperature, extraction time and ionic strength were optimized to achieve the best extraction efficiency. $10 \mathrm{mg}$ GIL-MCGO nanocomposites were used to extract $1 \mathrm{~mL}$ DNA sodium salt $\left(7 \mathrm{ng} \mu \mathrm{L}^{-1}\right)$ in the experiments. The shaker speed was $400 \mathrm{rpm}$. $0.04 \mathrm{~mol} \mathrm{~L}^{-1} \mathrm{BR}$ buffer was used to adjust the $\mathrm{pH}$ of solution.

Effect of pH value on extraction efficiency. In biological or environmental samples, the $\mathrm{pH}$ values of DNA solutions are often variable and may have influence on the extraction behavior of DNA with the coexistence of interfering matrix components/contaminants. ${ }^{42}$ To investigate the effect of $\mathrm{pH}$ on DNA extraction efficiency, solutions of DNA sodium salt with $\mathrm{pH}$ value ranging from 2-12 were prepared and subjected to magnetic solid-phase extraction with all other factors unchanged (temperature was $35^{\circ} \mathrm{C}$, extraction time was $30 \mathrm{~min}$, information of buffer system used is provided in ESI $\dagger$ ). Results are shown in Fig. 4(a). The extraction efficiencies of DNA were higher than $90 \%$ when $\mathrm{pH}$ varied from 2 to 4 . At $\mathrm{pH} 6$, the extraction efficiency decreased to around $80 \%$. These observations could be well explained by the electrostatic interaction between DNA and the GIL-MCGO nanocomposites. As illustrated in our previous work, ${ }^{43}$ the isoelectric point (pI) of GILMCGO nanocomposites is 6.3 (the zeta potential of GIL-

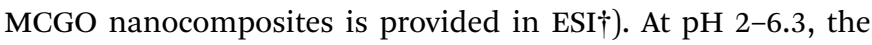

surface of GIL-MCGO nanocomposites is positively charged, while the DNA is negatively charged within the same $\mathrm{pH}$ range. Therefore, the strong electrostatic attraction between GILMCGO nanocomposites and DNA at a lower $\mathrm{pH}$ value facilitates the extraction of DNA and finally results in favorable
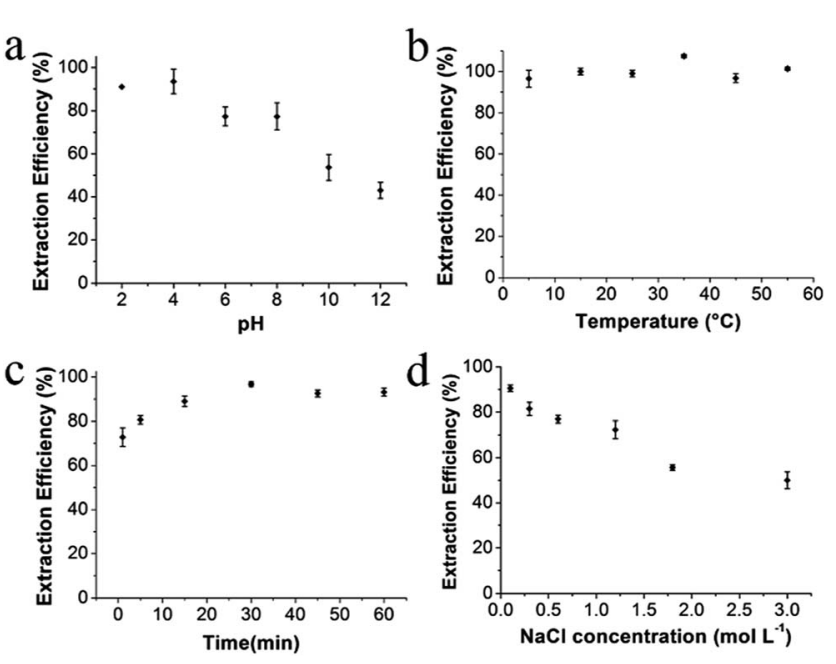

Fig. 4 Effects of (a) $\mathrm{pH}$, (b) temperature, (c) extraction time and (d) ionic strength. [diOTMG]Br-MCGO nanocomposites: $10 \mathrm{mg}$; DNA sodium salt: $7 \mathrm{ng} \mu \mathrm{L}^{-1}, 1 \mathrm{~mL}$; extraction time: $30 \mathrm{~min}$. 
extraction efficiency. At $\mathrm{pH}>6.3$, the surface of the GIL-MCGO nanocomposites turns to negatively charged and the electrostatic repulsion deteriorates the extraction of DNA. With the increase of $\mathrm{pH}$ value, the negative surface charges of GIL-MCGO nanocomposites gradually accumulate, leading to a decrease of DNA extraction efficiency. Thus, $\mathrm{pH}=4$ was selected for subsequent extraction.

Effect of temperature. Temperature is also one of the factors that need to be considered as the extraction properties of adsorbent material might be affected in the case of too high/low temperature. In this work, the DNA sodium salt sample solution was extracted by [diOTMG]Br-MCGO under the same condition ( $\mathrm{pH}$ was 4, extraction time was $30 \mathrm{~min}$ ) except temperature. Extraction results are shown in Fig. 4(b). It can be seen from the graph that the extraction efficiencies were almost the same and all higher than $96 \%$ from 5 to $55^{\circ} \mathrm{C}$. That is, GIL-MCGO nanocomposites in this work are stable and the extraction process is not susceptible to temperature within this range. Comprehensive consideration, $35{ }^{\circ} \mathrm{C}$ was selected for subsequent extraction.

Effect of extraction time. Extraction time is an important indicator to evaluate the performance of adsorbent materials. Good adsorbent should achieve high extraction efficiency in a short period of time. In order to investigate the relationship between extraction time and efficiency of GIL-MCGO nanocomposites, the DNA sodium salt sample was subjected to extraction for 1 to $60 \mathrm{~min}$ (temperature was $35{ }^{\circ} \mathrm{C}$, pH was 4 ). Fig. 4(c) shows the results. It can be seen that the extraction efficiency reached $78 \pm 4 \%$ within 1 minute. After 15 minutes, the extraction efficiency became higher than $90 \%$. At $\sim 30 \mathrm{~min}$, absorption and desorption of DNA reached an equilibrium, resulting in a maximum extraction efficiency. Thus, 30 min was used for subsequent extraction.

Effect of ionic strength. Usually, ionic strength shows an important effect on biomacromolecules extraction performance, and electrostatic interaction plays a major role in the extraction process. In this work, the effect of ionic strength was investigated by adding $\mathrm{NaCl}\left(0.1-3.0 \mathrm{~mol} \mathrm{~L}^{-1}\right)$ into the DNA sodium salt sample solution (temperature was $35{ }^{\circ} \mathrm{C}$, extraction time was $30 \mathrm{~min}$, pH was 4). From Fig. 4(d), we can see that the extraction efficiency is highest $(91 \pm 1 \%)$ at $\mathrm{NaCl}$ concentration of $0.1 \mathrm{~mol} \mathrm{~L}^{-1}$. When $\mathrm{NaCl}$ increased to 0.3 and $0.6 \mathrm{~mol} \mathrm{~L}^{-1}$, the extraction efficiencies dropped to $82 \pm 3 \%$ and $77 \pm 2 \%$ respectively. As further increase of ionic strength, an obviously decrease was observed on the extraction efficiency of DNA. At $\mathrm{NaCl}$ concentration of $3.0 \mathrm{~mol} \mathrm{~L}^{-1}$, only $50 \pm 4 \%$ of DNA has been extracted by GIL-MCGO nanocomposites. This observation indicates that increase of ionic strength diminished electrostatic interaction between GIL-MCGO nanocomposites and DNA.

\section{Extraction capacity of GIL-MCGO nanocomposites to DNA}

In order to evaluate the extraction capacity of the GIL-MCGO nanocomposites to DNA, $1.0 \mathrm{~mL}$ sample solution with various DNA concentrations (7-5000 ng $\mu \mathrm{L}^{-1}$ ) were prepared in a BR buffer with $\mathrm{pH} 4$ and treated with $10 \mathrm{mg}$ GIL-MCGO nanocomposites under $35{ }^{\circ} \mathrm{C}$. The amount of the extracted DNA at each concentration level was derived and illustrated in Fig. 5. It can be seen from Fig. 5 that the binding amount of DNA on GILMCGO nanocomposites increases quickly with DNA concentration. When DNA concentration increased to $2500 \mathrm{ng} \mu \mathrm{L}^{-1}$, the extraction capacity reached a plateau with a maximum extraction capacity of $233.0 \pm 0.4 \mathrm{mg} \mathrm{g}^{-1}$. What needs to be mentioned is that floccule was observed when DNA concentration exceeds $3000 \mathrm{ng} \mu \mathrm{L}^{-1}$, and the corresponding extraction capacity started to drop under such high concentrations. It was speculated that the GIL-MCGO nanocomposites get aggregated under very high DNA concentration, resulting in decreased extraction capacity. This phenomenon should not affect the application of GIL-MCGO nanocomposites, in general, the concentrations of DNA in biological samples are much lower. Table 1 compares the maximum DNA extraction capacity of the present composite with those of other materials reported in the literatures. It is obvious that the GIL-MCGO nanocomposites offers the highest extraction capacity for DNA.

\section{Comparison of $\mathrm{Fe}_{3} \mathrm{O}_{4}, \mathrm{MC}$, MCGO and GIL-MCGO}

In order to compare the DNA extraction performance of the GILMCGO nanocomposites, commercial $\mathrm{Fe}_{3} \mathrm{O}_{4}$ particles, magnetic chitosan particles and magnetic chitosan-graphene oxide composites, $1 \mathrm{~mL}$ DNA sodium salt $\left(7 \mathrm{ng} \mu \mathrm{L}^{-1}\right)$ has been extracted for $30 \mathrm{~min}$ by using these composites/particles under $35{ }^{\circ} \mathrm{C}$ at $\mathrm{pH} 4$, separately. As shown in Fig. 6, the GIL-MCGO nanocomposites extracted a much higher amount of DNA compared to $\mathrm{Fe}_{3} \mathrm{O}_{4}$ under the same condition. One of the reasons should be, unlike the $\mathrm{Fe}_{3} \mathrm{O}_{4}$ particles, the GIL-MCGO nanocomposites possess cationic framework that is capable of engaging in electrostatic interactions with the negatively charged phosphate backbone of DNA. Another reason is the surface area. Compare to magnetic chitosan (MC), the introduction of graphene oxide (GO) enlarged surface area of the composites. In the presence of catalysts, carboxyl group of GO chemically reacts with amine group of chitosan and consequently form chemical bond between GO and chitosan. But MCGO composites are easily aggregated and will affect its extraction performance. Immobilization of ionic liquids on the material enables them to have electrostatic repulsion accordingly prevent aggregation and promote the dispersion of the nanocomposites. Therefore, the extraction efficiency of GIL-MCGO nanocomposites are higher than both MC and MCGO composites.

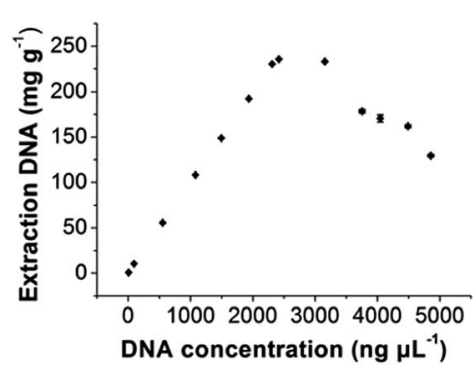

Fig. 5 Extraction capacity of GIL-MCGO nanocomposites for DNA. [diOTMG]Br-MCGO nanocomposites: $10 \mathrm{mg}$; DNA sodium salt: 7$5000 \mathrm{ng} \mu \mathrm{L}^{-1}, 1 \mathrm{~mL}$; $\mathrm{pH}$ : 4; extraction time: $30 \mathrm{~min}$. 
Table 1 An overview on recently reported methods for DNA extraction

\begin{tabular}{|c|c|c|c|}
\hline Materials & Method & $\begin{array}{l}\text { Extraction DNA } \\
\left(\mathrm{mg} \mathrm{g}^{-1}\right)\end{array}$ & References \\
\hline M-MSN & NanoDrop 1000 spectrophotometer & 121.6 & 44 \\
\hline $\mathrm{IL}-\mathrm{Fe}_{3} \mathrm{O}_{4}$ & UV-visible spectroscopy & 19.8 & 46 \\
\hline $\mathrm{PEI}-\mathrm{FePO}_{4}$ & PCR & 61.9 & 47 \\
\hline Fe\&Ni-mc-poly(HEMA-AdeM) & UV-visible spectroscopy & 91.8 & 48 \\
\hline
\end{tabular}

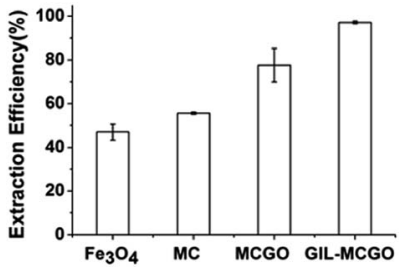

Fig. 6 DNA extraction by using different materials. Nanocomposites: $10 \mathrm{mg}$; DNA sodium salt: $7 \mathrm{ng} \mu \mathrm{L}^{-1}, 1 \mathrm{~mL}$; $\mathrm{pH}$ : 4; extraction time: $30 \mathrm{~min}$.

\section{The GIL-MCGO nanocomposites extraction preference on DNA with different bases}

In order to investigate extraction preference between the system and different basic groups, $2 \mathrm{mg}$ magnetic composite modified by different GILs have been used to extract $1 \mathrm{~mL}$ of $1000 \mathrm{nM}$ single strand DNAs with different sequence (same base number) under the same condition. The results are shown in Table 2. It can be seen that the structure of GIL modified on the surface of the nanocomposites influences extraction preference of ATCG ssDNA. For example, $88.5 \pm 0.02 \%$ of dT21 has been extracted by [TMG] $\mathrm{CHC}\left(\mathrm{CH}_{3}\right) \mathrm{COOH}-\mathrm{MCGO}$ while only $36.9 \pm$ $0.01 \%$ has been extracted by [diBTMG]Br-MCGO. Also, extraction efficiencies of ATCG ssDNA are different even when using the same GIL-MCGO nanocomposites as absorbent. For example, $95.00 \pm 0.01 \%$ of dG21 have been extracted by [TMG] $\mathrm{CH}_{2} \mathrm{CH}_{2} \mathrm{COOH}-\mathrm{MCGO}$ while only $54.9 \pm 0.03 \%$ of $\mathrm{C}$ ssDNA have been extracted. Different structure of GIL-MCGO nanocomposites have different extraction preference of basic groups. Therefore, we can select the most suitable GIL-MCGO nanocomposites to extract DNA with different sequences according to this table. For example, [TMG] $\mathrm{CH}_{2} \mathrm{CH}_{2} \mathrm{COOH}-$ MCGO can be used to extract DNA that has high percentage of base dG21, while [TMG] $\mathrm{CHC}(\mathrm{COOH}) \mathrm{CH}_{2} \mathrm{COOH}-\mathrm{MCGO}$ can be used to extract DNA with high percentage of base dC21.

\section{Method validation}

The proposed method was validated by precision experiment and repeatability experiment. Apparatus precision was researched by analyzing DNA solution for three times by NanoDrop under the same condition. The results indicate that the RSD was $4.9 \%(n=3)$, showing the precision of the NanoDrop is excellent. Repeatability experiment was performed by taking three copies of the same sample measured under the same condition, respectively. The value of RSD was $5.1 \%(n=3)$, showing the method has good repeatability.

\section{Regeneration studies}

A series of extraction-desorption experiments were carried out to evaluate the possibility of reusability and regeneration of GILMCGO nanocomposites. $0.04 \mathrm{~mol} \mathrm{~L}^{-1} \mathrm{BR}$ buffer $(\mathrm{pH}=10)$ was selected as stripping reagent (The desorption efficiency is provided in ESI $\dagger$ ). After desorption, the regenerated GIL-MCGO nanocomposites has been utilized to extract DNA again. Four consecutive extraction-desorption cycles were taking. The

Table 2 Extraction efficiencies of ATCG by using different GIL-MCGO nanocomposites

\begin{tabular}{|c|c|c|c|c|}
\hline \multirow[b]{2}{*}{ GIL-MCGO nanocomposites } & \multicolumn{4}{|c|}{ Extraction efficiencies (\%) } \\
\hline & $\mathrm{dA} 21$ & $\mathrm{dT} 21$ & $\mathrm{dC} 21$ & dG21 \\
\hline$[\mathrm{TMG}] \mathrm{CH}_{2} \mathrm{COOH}$ & $79.9 \pm 0.03$ & $88.1 \pm 0.03$ & $93.7 \pm 0.08$ & $85.5 \pm 0.01$ \\
\hline$[\mathrm{TMG}] \mathrm{CH}_{2} \mathrm{CH}_{2} \mathrm{COOH}$ & $55.9 \pm 0.06$ & $66.4 \pm 0.02$ & $54.9 \pm 0.03$ & $95.0 \pm 0.01$ \\
\hline$[\mathrm{TMG}] \mathrm{CH}_{2} \mathrm{CH}(\mathrm{OH}) \mathrm{COOH}$ & $102.3 \pm 0.03$ & $117.3 \pm 0.05$ & $118.3 \pm 0.08$ & $18.4 \pm 0.08$ \\
\hline$[\mathrm{TMG}] \mathrm{CHC}(\mathrm{COOH}) \mathrm{CH}_{2} \mathrm{COOH}$ & $68.3 \pm 0.1$ & $73.4 \pm 0.07$ & $96.5 \pm 0.02$ & $56.6 \pm 0.2$ \\
\hline$[\mathrm{TMG}] \mathrm{C}(\mathrm{COOH}) \mathrm{CHCOOH}$ & $97.7 \pm 0.05$ & $78.5 \pm 0.06$ & $83.3 \pm 0.1$ & $55.1 \pm 0.05$ \\
\hline$[\mathrm{diBTMG}] \mathrm{Br}$ & $63.2 \pm 0.06$ & $36.9 \pm 0.01$ & $32.6 \pm 0.06$ & $30.5 \pm 0.07$ \\
\hline [diHTMG]Br & $41.4 \pm 0.06$ & $47.8 \pm 0.01$ & $43.7 \pm 0.1$ & $54.5 \pm 0.05$ \\
\hline [diOTMG]Br & $62.0 \pm 0.03$ & $88.8 \pm 0.02$ & $85.2 \pm 0.07$ & $62.8 \pm 0.2$ \\
\hline
\end{tabular}


results are illustrated in Fig. 7. Only a slight loss in the extraction efficiency of DNA after four cycles, proving good performance and recyclability of the GIL-MCGO nanocomposites in the DNA extraction.

\section{Extraction of DNA from a complex matrix}

Highly accurate and reliable DNA analysis is the foundation to various biological applications. Interfering components or contaminants in biological samples, such as metal ions and proteins, are known to reduce the sensitivity and reproducibility of DNA analysis. If the sample is not sufficiently purified from contaminants, the feasibility of downstream experiments may be affected in some cases. Therefore, it is important to determine the performance of GIL-MCGO nanocomposites for extracting DNA from complex samples.

The extraction performance of the GIL-MCGO nanocomposites was evaluated for $2000 \mathrm{bp}$ DNA sodium salt in the presence of $\mathrm{NaCl}, \mathrm{KCl}, \mathrm{CaCl}_{2}, \mathrm{MgCl}_{2}$. Results are shown in Fig. 8(a). It can be seen from Fig. 8(a) that the extraction efficiencies of DNA from the metal ions matrix sample are similar to those from the neat solution, only a very small to negligible variation in extraction efficiencies was observed for the GILMCGO nanocomposites ([TMG] $\mathrm{CH}_{2} \mathrm{CH}_{2} \mathrm{COOH}-\mathrm{MCGO}$ and [diOTMG]Br-MCGO as representatives).

The effect of protein on the extraction efficiency of DNA was researched by preparing aqueous 2000 bp DNA sodium salt solution containing bovine hemoglobin (BHb) as a model protein. The extraction efficiencies of both DNA and $\mathrm{BHb}$ were investigated at $\mathrm{pH}$ 4. As shown in Fig. 8(b), GIL-MCGO nanocomposites exhibit different extraction behavior on DNA and $\mathrm{BHb}$. When $\mathrm{BHb}$ spiked into the solution, the extraction efficiencies of both DNA and BHb decreased in some extent. But DNA still showed relatively high extraction efficiencies while $\mathrm{BHb}$ were almost unabsorbed in this work. At $\mathrm{pH} 4$, electrostatic attraction has taken place between the opposite-charged DNA and GIL-MCGO nanocomposites (pI 6.3). However, BHb (pI 6.8) possesses the same positive charge with GIL-MCGO nanocomposites in the buffer, which hinders the extraction of $\mathrm{BHb}$. Therefore, GIL-MCGO nanocomposites may be used to purify DNA from $\mathrm{BHb}$ under this experimental condition.

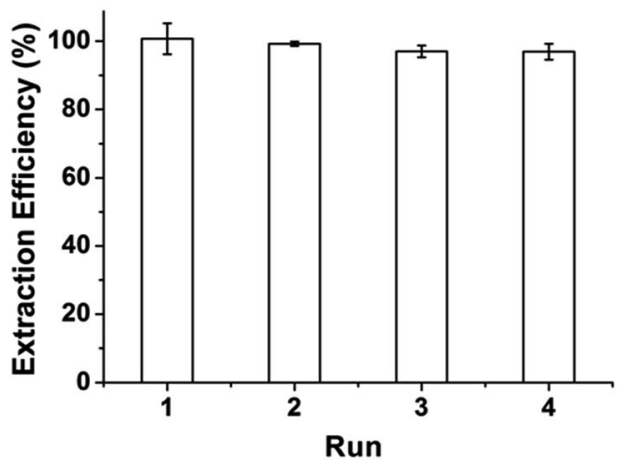

Fig. 7 Extraction efficiency of DNA for different cycles. [diOTMG]BrMCGO nanocomposites: $10 \mathrm{mg}$; DNA sodium salt: $7 \mathrm{ng} \mu \mathrm{L}^{-1}, 1 \mathrm{~mL} ; \mathrm{pH}$ : 4; extraction time: $30 \mathrm{~min}$.

\section{Extraction of DNA from human whole blood and bacterial cell} lysate

Before DNA was extracted from the bacterial cell lysate actual sample, there was a DNA purification process that removes proteins and cell membranes. After the purification was completed, most of the protein in the cell solution will be removed, and then GIL-MCGO was used to extract the DNA. Under strong alkaline conditions, plasmid DNA and genomic DNA are simultaneously released from the cells and denatured. In the presence of neutral $\mathrm{pH}$ and high salt concentration conditions, plasmid DNA was rapidly refolded to a soluble state, and genomic DNA cross-links to form an insoluble network structure, while under high salt conditions, sodium dodecyl sulfate (SDS) and denatured proteins combine to form a precipitate, and the average two amino acids bind to one SDS molecule, while the $\mathrm{K}^{+}$in the solution replaces $\mathrm{Na}^{+}$in the SDS to form an insoluble potassium dodecyl sulfate (PDS), and the genomic DNA was easily coprecipitated by PDS. Genomic DNA and denatured proteins and cell debris will form a precipitate under the action of detergent SDS. At this point most of the protein in the solution has precipitated completely. When nanoparticles were extracted from plasmid DNA, impurities such as proteins have been removed.

The yield and quality of isolated DNAs from the biological sample matrices were estimated by measuring the absorbance at $260 \mathrm{~nm}$ (A260) and the absorbance ratio at A260 $\mathrm{nm}$ and
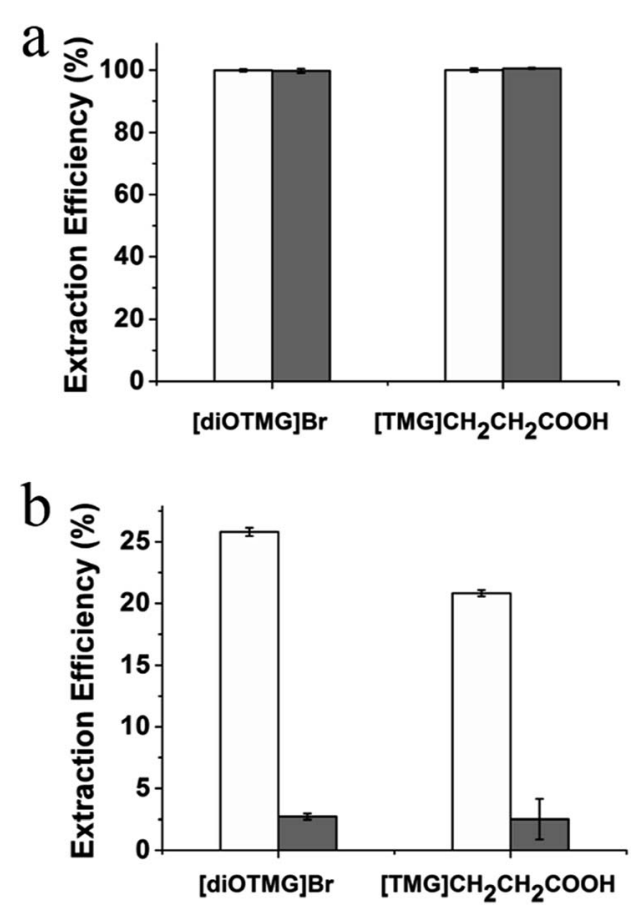

Fig. 8 (a) Comparison of DNA extraction efficiencies from both a neat solution (black bars) and a matrix containing metal ions $(\mathrm{NaCl}, \mathrm{KCl}$, $\mathrm{CaCl}_{2}, \mathrm{MgCl}_{2}$, grey bars); (b) extraction results of mixed sample. Black bars represent the extraction efficiencies of DNA, while grey bars represent the extraction efficiencies of $\mathrm{BHb}$. Nanocomposites: $10 \mathrm{mg}$; DNA sodium salt: $7 \mathrm{ng} \mathrm{LL}^{-1}$ (a), DNA sodium salt and BHb: $1000 \mathrm{ng}$ $\mu \mathrm{L}^{-1}$ (b), $1 \mathrm{~mL} ; \mathrm{pH}$ : 4; extraction time: $30 \mathrm{~min}$. 


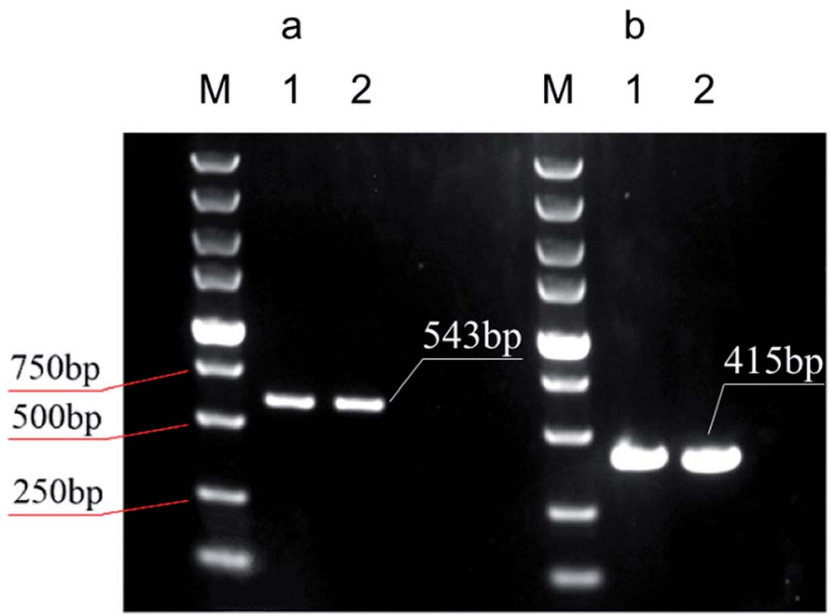

Fig. 9 The electrophotograms for the PCR products. (a) Human whole blood sample. M: DNA molecular weight marker, lane 1: PCR product from blood DNA extracted by commercial kits, lane 2: PCR products from blood DNA extracted by GIL-MCGO nanocomposites; (b) E. coli cell lysate sample. M: DNA molecular weight marker, lane 1: PCR product from $E$. coli cell lysate extracted by commercial kits, lane 2: PCR products from E. coli cell lysate extracted by GIL-MCGO nanocomposites.

A280 nm (A260/A280). The concentration of the isolated DNA was detected according to NanoDrop 2000 spectrophotometer and the yield of DNA was calculated based on the concentration and the volume of the eluate. $8.65 \mu \mathrm{g}$ of human blood genomic DNA and $19.6 \mu \mathrm{g}$ of plasmid DNA were isolated from $200 \mu \mathrm{L}$ of human whole blood and $1.5 \mathrm{~mL}$ of $E$. coli cell culture using GILMCGO nanocomposites. The A260/A280 ratio of DNA recovered from human whole blood and $E$. coli cell lysate were $c a .1 .87$ and 1.85 , respectively, indicating to the isolated DNA template was of high purity and favorable quality.

Fig. 9 illustrates the electrophoretograms for the PCR products. It can be seen that the $543 \mathrm{bp}$ and $415 \mathrm{bp}$ amplified products from human whole blood gene and $E$. coli cell lysate are clearly from the corresponding samples by using the GILMCGO nanocomposite as the adsorbent is comparable to those obtained using the commercial DNA extraction kit. The successful PCR amplifications demonstrate that the DNAs isolated from both human whole blood and $E$. coli cell lysate are of high purity, indicating the favorable efficiency of GIL-MCGO nanocomposites for DNA extraction.

\section{Conclusions}

The GIL-MCGO nanocomposite based solid phase extraction provides an efficient method for DNA extraction/purification. The retained DNAs can be readily recovered by simply using BR buffer as stripping reagent. The GIL-MCGO nanocomposite can be regenerated and reused without any degradation of DNA extraction efficiency. The solid phase extraction method based on GIL-MCGO nanocomposites have been demonstrated with the extraction of DNA from a series of real sample matrices, including ssDNA sample, salmon sperm DNA sodium salt, human whole blood and $E$. coli cell lysate. The DNA extracted by using the GIL-MCGO nanocomposites are well suitable for PCR amplifications. In addition, an initial study on the interaction between GIL-MCGO and DNA is conducted and the preference of GIL-MCGO absorbing DNA with varying base composition is investigated. Such work can guide the future selection process of optimum GIL-MCGO nanocomposite for extraction of any specific DNA sequence.

\section{Conflicts of interest}

There are no conflicts to declare.

\section{Acknowledgements}

The authors greatly appreciate the financial supports by the Natural Science Foundation of Hunan Province (No. 2018JJ3342).

\section{References}

1 K. D. Clark, O. Nacham, H. Yu, T. Li, M. M. Yamsek, D. R. Ronning and J. L. Anderson, Anal. Chem., 2015, 87, 1552-1559.

2 O. Nacham, K. D. Clark and J. L. Anderson, Anal. Chem., 2016, 88, 7813-7820.

$3 \mathrm{~K} . \mathrm{Xu}, \mathrm{Y}$. Wang, H. Zhang, Q. Yang, X. Wei, P. Xu and Y. Zhou, Microchim. Acta, 2017, 184, 4133-4140.

4 J. Wen, L. A. Legendre, J. M. Bienvenue and J. P. Landers, Anal. Chem., 2008, 80, 6472-6479.

5 E. He, T. Cao, L. Cai, D. Guo, Y. Zhou, X. Zhang and Z. Li, RSC Adv., 2018, 8, 39561-39566.

6 L. Monteiro, D. Bonnemaison, A. Vekris, K. G. Petry, J. Bonnet, R. Vidal, J. Cabrita and F. Mégraud, J. Clin. Microbiol., 1997, 35, 995-998.

7 A. Ziegler, A. Koch, K. Krockenberger and A. Großhennig, Hum. Genet., 2012, 131, 1627-1638.

8 R. Patel, J. T. Kvach and P. Mounts, Microbiology, 1986, 132, 541-551.

9 C. W. Price, D. C. Leslie and J. P. Landers, Lab Chip, 2009, 9, 2484-2494.

10 L. Dauphin, K. Stephens, S. Eufinger and M. Bowen, J. Appl. Microbiol., 2010, 108, 163-172.

11 J. Löffler, H. Hebart, U. Schumacher, H. Reitze and H. Einsele, J. Clin. Microbiol., 1997, 35, 3311-3312.

12 M. Šafaříková and I. Šafařík, J. Magn. Magn. Mater., 1999, 194, 108-112.

13 Y. Huang, Y. Wang, Q. Pan, Y. Wang, X. Ding, K. Xu, N. Li and Q. Wen, Anal. Chim. Acta, 2015, 877, 90-99.

14 K. Xu, Y. Wang, X. Ding, Y. Huang, N. Li and Q. Wen, Talanta, 2016, 148, 153-162.

15 A. Rimola, D. Costa, M. Sodupe, J. F. Lambert and P. Ugliengo, Chem. Rev., 2013, 113, 4216-4313.

16 M. Deng, C. Jiang and L. Jia, Anal. Chim. Acta, 2013, 771, 3136.

17 J. P. Chen, P. C. Yang, Y. H. Ma and T. Wu, Carbohydr. Polym., 2011, 84, 364-372. 
18 Y. C. Chang and D. H. Chen, J. Colloid Interface Sci., 2005, 283, 446-451.

19 P. E. Podzus, M. E. Daraio and S. E. Jacobo, Phys. B, 2009, 404, 2710-2712.

20 A. P. Tiwari, R. K. Satvekar, S. S. Rohiwal, V. A. Karande, A. V. Raut, P. G. Patil, P. B. Shete, S. J. Ghosh and S. H. Pawar, RSC Adv., 2015, 5, 8463-8470.

21 W. Ma, F. Q. Ya, M. Han and R. Wang, J. Hazard. Mater., 2007, 143, 296-302.

22 G. Y. Li, Y. R. Jiang, K. L. Huang, P. Ding and J. Chen, J. Alloys Compd., 2008, 466, 451-456.

23 L. Li, C. Luo, X. Li, H. Duan and X. Wang, Int. J. Biol. Macromol., 2014, 66, 172-178.

24 N. Zhang, H. Qiu, Y. Si, W. Wang and J. Gao, Carbon, 2011, 49, 827-837.

25 E. Hashemi, O. Akhavan, M. Shamsara, S. Valimehr and R. Rahighi, RSC Adv., 2014, 4, 60720-60728.

26 Q. Liu, J. Shi, J. Sun, T. Wang, L. Zeng and G. Jiang, Angew. Chem., Int. Ed., 2011, 50, 5913-5917.

27 J. Wu, H. Zhao, D. Xiao, P. H. Chuong, J. He and H. He, J. Chromatogr. A, 2016, 1454, 1-8.

28 S. D. Pan, L. X. Zhou, Y. G. Zhao, X. H. Chen, H. Y. Shen, M. Q. Cai and M. C. Jin, J. Chromatogr. A, 2014, 1362, 34-42. 29 R. D. Rogers and K. R. Seddon, Science, 2003, 302, 792-793. 30 K. D. Clark, M. Sorensen, O. Nacham and J. L. Anderson, RSC Adv., 2016, 6, 39846-39851.

31 M. D. Joshi and J. L. Anderson, RSC Adv., 2012, 2, 5470-5484. 32 Y. Gao, S. W. Arritt, B. Twamley and J. n. M. Shreeve, Inorg. Chem., 2005, 44, 1704-1712.
33 X. Ding, L. Li, Y. Wang, J. Chen, Y. Huang and K. Xu, J. Sep. Sci., 2014, 37, 3539-3547.

34 Q. Zeng, Y. Wang, N. Li, X. Huang, X. Ding, X. Lin, S. Huang and X. Liu, Talanta, 2013, 116, 409-416.

35 X. Ding, Y. Wang, Q. Zeng, J. Chen, Y. Huang and K. Xu, Anal. Chim. Acta, 2014, 815, 22-32.

36 L. Vidal, M. L. Riekkola and A. Canals, Anal. Chim. Acta, 2012, 715, 19-41.

37 E. Wanigasekara, S. Perera, J. A. Crank, L. Sidisky, R. Shirey, A. Berthod and D. W. Armstrong, Anal. Bioanal. Chem., 2010, 396, 511-524.

38 H. Yang, C. Shan, F. Li, D. Han, Q. Zhang and L. Niu, Chem. Commun., 2009, 45, 3880-3882.

39 Y. Huang, Y. Wang, Y. Wang, Q. Pan, X. Ding, K. Xu, N. Li and Q. Wen, RSC Adv., 2016, 6, 5718-5728.

40 A. S. K. Kumar and N. Rajesh, RSC Adv., 2013, 3, 2697-2709. 41 L. Fan, C. Luo, X. Li, F. Lu, H. Qiu and M. Sun, J. Hazard. Mater., 2012, 215, 272-279.

42 N. Li, Y. Wang, K. Xu, Q. Wen, X. Ding, H. Zhang and Q. Yang, RSC Adv., 2016, 6, 84406-84414.

43 X. Ding, Y. Wang, Y. Wang, Q. Pan, J. Chen, Y. Huang and K. Xu, Anal. Chim. Acta, 2015, 861, 36-46.

44 X. Li, J. Zhang and H. Gu, Langmuir, 2011, 27, 6099-6106.

45 X. W. Chen, Q. X. Mao, J. W. Liu and J. H. Wang, Talanta, 2012, 100, 107-112.

46 M. Ghaemi and G. Absalan, Microchim. Acta, 2014, 181, 4553.

47 L. L. Hu, B. Hu, L. M. Shen, D. D. Zhang, X. W. Chen and J. H. Wang, Talanta, 2015, 132, 857-863.

48 K. Köse, Process Biochem., 2016, 51, 1644-1649. 